\title{
Usulan Perbaikan Rancangan Tata Letak Penyimpanan Bahan Baku Berdasarkan Kriteria Pemakaian Bahan
}

\author{
Lamto Widodo $^{1}$, Nofi Erni ${ }^{1}$ dan Rizky Sari Nuranisa ${ }^{1}$ \\ ${ }^{1}$ Program Studi Teknik Industri, Universitas Tarumanagara \\ Jl. Letjen S. Parman No.1, Jakarta Barat 11510 \\ E-mail: lamtow@yahoo.com, nuranisarizky@gmail.com
}

\begin{abstract}
Abstrak - PT. Talkindo Selaksa Anugrah merupakan perusahaan yang bergerak di bidang manufaktur makanan dan minuman. Guna memperlancar proses pemenuhan permintaan bahan baku dari outlet-outlet untuk diproduksi, dibutuhkan pengelolaan yang baik dalam penyimpanan bahan baku. Pengalokasian bahan baku di area Dry J.CO yang disimpan masih menggunakan penyimpanan secra random/acak yang berakibat terlambatnya pasokan bahan baku ke bagian pengiriman, karena terlalu lamanya waktu untuk mencari bahan baku dan bertambahnya waktu perjalanan operator. Kurang lancarnya pasokan bahan baku ke bagian pengiriman menyebabkan menurunnya produktivitas dari bagian pengiriman. Penelitian ini bertujuan melakukan perbaikan rancangan tata letak penyimpanan bahan baku sehingga mengurangi waktu mencari bahan baku, mengurangi jarak perjalanan operator dalam pengambilan dan pengiriman bahan baku ke bagian pengiriman serta mengingkatkan utilitas ruang gudang. Pendekatan relayout menggunakan prinsip Seiton dari 5S serta memperhatikan tingkat popularity komoditi yang disimpan, kondisi ruangan yang tersedia. Hasil penelitian menunjukkan rancangulang tata letak penyimpanan bahan baku berdasarkan kriteria popularity dapat mengurangi waktu proses pergudangan dari 20 menit 16 detik menjadi 13 menit 14 detik, serta dengan adanya peningkatan utilitas ruang gudang dari $65,47 \%$ menjadi $78,69 \%$ yang berdampak pada berkurangnya perjalanan operator dalam mengambil dan mengirim ke bagian pengiriman.
\end{abstract}

Abstract - PT. Talkindo Selaksa Anugrah is a company engaged in manufacturing of food and beverages. In order to expedite the process of fulfilling the demand of raw materials for production outlets, it takes good management in the storage of raw materials. Allocation of raw materials in the area of "Dry J.CO" stored still use random storage system resulting delay of supply of raw materials to the delivery, because it takes too much time to find raw materials and also increase operator's travel time. The delay of supply of raw materials to the delivery causes decreased productivity of the delivery departement. This research purpose to redesign the storage system and designing better layout so as to reduce the time looking for raw materials, reducing the travel distance operator and increase the utility of warehouse' storage space. The re-layout approach is done by applying the principles of the Seiton method (5S) and also huge attention to the raw material itself, called as "popularity of commodity factors" and the availbility of the storage. Based on the analysis and the results of data processing show that the layout of the storage of raw materials based on the criteria of popularity can reduce warehouse processing time of 20 minutes 16 seconds to 13 minutes 14 seconds, and also the increased utility of warehouse space from $65,47 \%$ to $78,69 \%$ as the impact of the reduction of operator assistance in taking and sending to the delivery departement.

Keywords - System Storage, Popularity, Seiton, Utilities

\section{PENDAHULUAN}

Latar Belakang Penelitian

Tingginya persaingan di bidang industri dalam meningkatkan kualitas barang atau jasanya, menuntut perusahaan untuk melakukan tindakan 
perbaikan, termasuk untuk mengoptimalkan sistem pergudangan.

PT. Talkindo Selaksa Anugrah adalah perusahaan yang mempunyai 3 merek usaha yaitu "Breadtalk" (franchise), "J.CO Donuts \& Coffee" dan "Roppan". Gudang bahan baku terpusat pada satu tempat, yaitu di Kawasan Industri Gudang Taman Tekno blok D1 No. 11 BSD 11630 Tangerang. Lokasi penyimpanan barang bagian J.CO dikelompokkan berdasarkan karakteristik dari barang tersebut yaitu area Dry J.CO, Premix J.CO, Packaging J.CO, Utensil J.CO, Ruang AC J.CO, Chiller J.CO dan Freezer J.CO.

Seiring dengan meningkatnya minat pasar dan penambahan outlet-outlet baru, perusahaan mengalami masalah dengan penyimpanan bahan baku. Salah satu faktor terpenting dalam sistem pergudangan yaitu tata letak penyimpanan barang, sehingga dibutuhkan pengaturan untuk membantu prosesnya menjadi lebih optimal.

Kondisi saat ini, tidak terdapat sistem penyimpanan bahan baku yang baik dan volume persediaan bahan baku yang lebih banyak dari kapasitas rak penyimpanan yang tersedia. Masalah terbesar terjadi pada dengan area Dry J.CO, area bahan baku jenis kering, yang menjadi fokus pada penelitian ini. Dalam menyelesaikan masalah, digunakan metode Seiton dan kriteria popularity guna merancang tata letak penyimpanan bahan baku.

\section{Rumusan Masalah}

Lingkup penelitian adalah di area penyimpanan Dry J.CO, pada area ini sistem penyimpanan yang diterapkan saat ini adalah kebijakan penyimpanan random atau acak sehingga letak bahan baku berubah-ubah setiap kali terjadi kedatangan bahan baku dari pemasok, hal tersebut terjadi karena bila terdapat suatu bahan baku kekurangan atau kehabisan persediaan maka tempat tersebut diisi oleh bahan baku lainnya.

Efek yang timbul dari sistem penyimpanan ini adalah sistem penempatan bahan baku yang tidak terstandar dan terbuangnya waktu untuk aktivitas pencarian bahan baku. Selain itu utilitas ruang gudang yang belum optimal, sehingga jika persediaan sedang tinggi ada beberapa bahan baku yang tidak memiliki tempat dan terpaksa ditempatkan di lorong/gang dan hal ini sangat mengganggu proses penyimpanan, pencarian maupun pengambilan bahan baku.

\section{Batasan Masalah}

Adapun yang menjadi batasan dalam penelitian ini adalah (1) penelitian dilakukan pada lokasi penyimpanan area Dry J.CO; (2) Data persediaan yang dibandingkan adalah data persediaan bahan baku di area Dry J.CO bulan September 2011 September 2012. Data merupakan data primer yang diambil langsung dari lapangan.

Metode yang digunakan untuk memperbaiki tata letak penyimpanan bahan baku adalah Seiton.

\section{Tujuan dan Manfaat Penelitian}

Tujuan dari penelitian ini adalah melakukan perbaikan perancangan tata letak penyimpanan bahan baku di area Dry J.CO agar dapat mempersingkat waktu proses pergudangan serta mengoptimalkan utilitas ruang gudang.

\section{TINJAUAN PUSTAKA}

\section{Gudang}

Gudang dapat didefinisikan sebagai tempat yang dibebani tugas untuk menyimpan barang yang akan dipergunakan dalam produksi sampai barang diminta sesuai dengan jadwal produksi [1]

\section{Perencanaan Tata Letak Gudang}

Dalam merencanakan dan merancang sistem penyimpanan dan gudang kita patut mempertimbangkan beberapa obyektif, yaitu: utilisasi luas lantai, utilisasi peralatan, utilisasi pekerja, kemudahan akses seluruh barang dan perlindungan terhadap seluruh barang. Tujuan dari perencanaan tata letak/layout gudang yaitu (1) mengefektifkan penggunaan ruang; (2) memberikan material handling yang efisien; (3) untuk meminimalkan biaya penyimpanan; (4) untuk memberikan fleksibilitas maksimum; (5) menyediakan pengaturan rumah tangga produksi yang baik [4].

\section{Tata Letak Barang}

Tata letak barang atau biasa disebut layout barang merupakan suatu metode peletakkan barang dalam gudang untuk mempermudah, mempercepat dan meningkatkan efisiensi dari gudang tersebut dalam menampung barang maupun mengalirkan permintaan barang kepada pihak konsumen [2].

Dalam melakukan pengaturan tata letak barang ada beberapa hal yang harus diperhatikan yaitu sistem pengukuran kecepatan yang baik dan sistem pengendalian yang baik. Sistem pengukuran kecepatan ini memperhatikan barang berdasarkan 
klasifikasi arus aliran barang yaitu slow moving, medium moving dan fast moving [6].

Untuk slow moving ditempatkan di bagian yang sulit dijangkau dengan alasan karena barang tersebut jarang untuk dipesan atau akan berada di gudang dengan waktu yang cukup lama. Untuk barang medium moving ditempatkan di bagian tengah gudang yang cukup terjangkau. Sedangkan untuk barang fast moving ditempatkan di bagian yang mudah terjangkau agar dapat memudahkan dalam pengambilan barang sehingga efisiensi akan menjadi lebih tinggi.

\section{Metode Seiton}

Pada proses Seiton (rapi), yang harus diperhatikan yaitu membenahi tempat penyimpanan [3]. Berikut adalah hal-hal yang dilakukan dalam kegiatan membenahi tempat penyimpanan, antara lain (1) membersihkan sebelum merapikan; (2) membuat denah tempat penyimpanan; (3) membuat warna lantai pada tempat kerja (strategi pengecatan); (4) menggambar garis di lantai; (5) menerapkan papan petunjuk dan strategi pelabelan (rapi visual); (6) merubah sistem penyimpanan tertutup menjadi terbuka.

Salah satu konsep dari 5S yaitu Seiton yang berarti rapi. Konsep ini sesuai dengan kasus di lapangan dimana problem yang dihadapi adalah penumpukan barang di gudang, termasuk metode labelisasi yang kurang baik sehingga terjadi kelambatam dalam proses pengambilan bahan baku. Rapi berarti meletakkan barang pada lokasi yang paling tepat/sistematis.

Setiap barang yang masih diperlukan dalam pekerjaan, harus memiliki suatu tempat penyimpanan yang tetap dan jelas status keberadaannya. Setiap item dan lokasi penyimpanan hendaknya mempunyai nama, alamat lokasi penyimpanan atau kode identifikasi (label) yang standar dan jelas. Selain itu dalam menentukan penempatan item, didasarkan pada prioritas berdasarkan frekuensi pemakaian (contoh: sering dipakai, jarang dipakai, selalu dipakai).

Metode penyimpanan dikatakan lebih baik bila setiap orang dapat melihat, mengeluarkan dan mengembalikan barang dengan mudah dan jelas. Tujuan utama dari konsep seiton adalah penyimpanan fungsional (menghilangkan ketidakpastian peletakkan barang) dan untuk menghilangkan kegiatan yang tidak perlu (mengurangi resiko kehilangan/kesalahan pengambilan barang, menghilangkan pemborosan waktu untuk mencari barang).

Keuntungan yang didapatkan dengan penerapan konsep Seiton atau rapi ini adalah (1) dapat mengurangi kerugian waktu yang disebabkan lamanya mencari barang; (2) dapat memudahkan memantau barang dan tempat jika terdapat barang yang hilang dan mudah terdeteksi; (3) dengan tertata rapinya barang dapat pula mencegah terjadinya kecelakaan kerja; menempatkan/menata barang pada tempat yang paling tepat; (5) adanya tanda petunjuk dan batas pada tiap barang/tempat penyimpanan sehingga dapat mengurangi kesalahan pengambilan barang.

Langkah-langkah yang perlu diperhatikan dalam penerapan konsep rapi ini antara lain melakukan inventarisasi barang dan memberikan nama/kode klasifikasi dari barang-barang yang masih berguna. Pengelompokkan terhadap barang-barang tersebut dapat dilihat diantaranya dari (1) frekuensi pemakaian, yang terdiri dari frekuensi rendah/jarang, frekuensi sedang/kadang-kadang, dan frekuensi tinggi/sering; (2) keseragaman alat; (3) fungsional, yaitu seperangkat alat yang berfungsi untuk mesin tertentu; (4) batasan waktu, dimana terdapat arsip, atau laporan untuk bulanan, atau satu tahun.

Melakukan inventarisasi lokasi dan menentukan lokasi penyimpanan barang sesuai klasifikasi dan juga member nama/ kode lokasi. Perlu diingat bahwa penentuan lokasi penempatan barang harus mempertimbangkan sifat barang yang akan disimpan.

Menempatkan barang pada lokasi yang telah ditentukan. Tempat penyimpanan yang tepat harus (1) mudah dalam mencari, mengambil, dan mengembalikan barang atau alat yang digunakan; (2) tempat penyimpanan alat atau barang tersebut tidak terlalu jauh dari lokasi penggunaannya; (3) barang atau alat yang mempunyai fungsi/kegunaan yang sama hendaknya tempat penyimpanannya pada lokasi yang sama; (4) Jumlah tempat penyimpanan yang digunakan untuk menyimpan barang atau alat harus diminimalkan, agar tidak mengganggu jalannya proses produksi serta mempertimbangkan tata letak area kerja yang telah ada; (5) membuat katalog/peta lokasi barang dan tempatkan di tempat yang mudah dilihat oleh semua orang. 


\section{METODOLOGI PENELITIAN}

Metodologi penelitian diawali dengan melakukan penelitian pendahuluan dengan tujuan mendapatkan informasi mengenai kondisi gudang di PT.Talkindo Selaksa Anugrah khususnya area Dry J.CO.

Penelitian dilakukan dengan pengamatan langsung tentang proses penerimaan, proses penyimpanan, proses persiapan dan tata letak area penyimpanan. Mengidentifikasikan masalah-masalah yang terjadi yaitu sistem penempatan bahan baku yang tidak terstandar dan terbuangnya waktu untuk aktivitas pencarian bahan baku dan utilitas ruang gudang yang belum optimal, kemudian melakukan studi literatur.

Proses pengumpulan data dilakukan dengan metode wawancara, pengamatan langsung, dan pengumpulan data sekunder yaitu data-data tertulis yang diberikan pihak perusahaan.

Dari hasil pengumpulan data itu dilanjutkan kepada tahap pengolahan data, yaitu dengan cara menggunakan metode Seiton yang diintegrasikan dengan kriteria Popularity untuk merancang tata letak penyimpanan bahan baku yang lebih terstandar dan untuk meningkatkan utilitas ruang gudang maka dilakukan perhitungan kebutuhan dan kapasitas rak penyimpanan, maka pada akhir usulan dilakukan penambahan rak penyimpanan. Dalam perancangan rak tersebut tidak membahas sisi teknis seperti gaya dan kekuatannya.

Tahap analisis berisi perbandingan rancangan kondisi sebelum dan sesduah dilakukan usulan perbaikan dan rangkuman dari hasil penelitian yang dilakukan secara keseluruhan. Solusi yang diberikan dengan melakukan usulan perbaikan terhadap sistem penyimpanan bahan baku dan utilitas ruang gudang.

\section{IV.HASIL DAN PEMBAHASAN}

\section{Flow Process (Unload-Loading)}

Berbagai proses pergudangan (Unload-Loading) meliputi proses barang datang dari pemasok hingga barang diambil lagi dari gudang untuk dikirim ke bagian persiapan pengiriman untuk dikirim ke masing-masing outlet (Gambar 2).

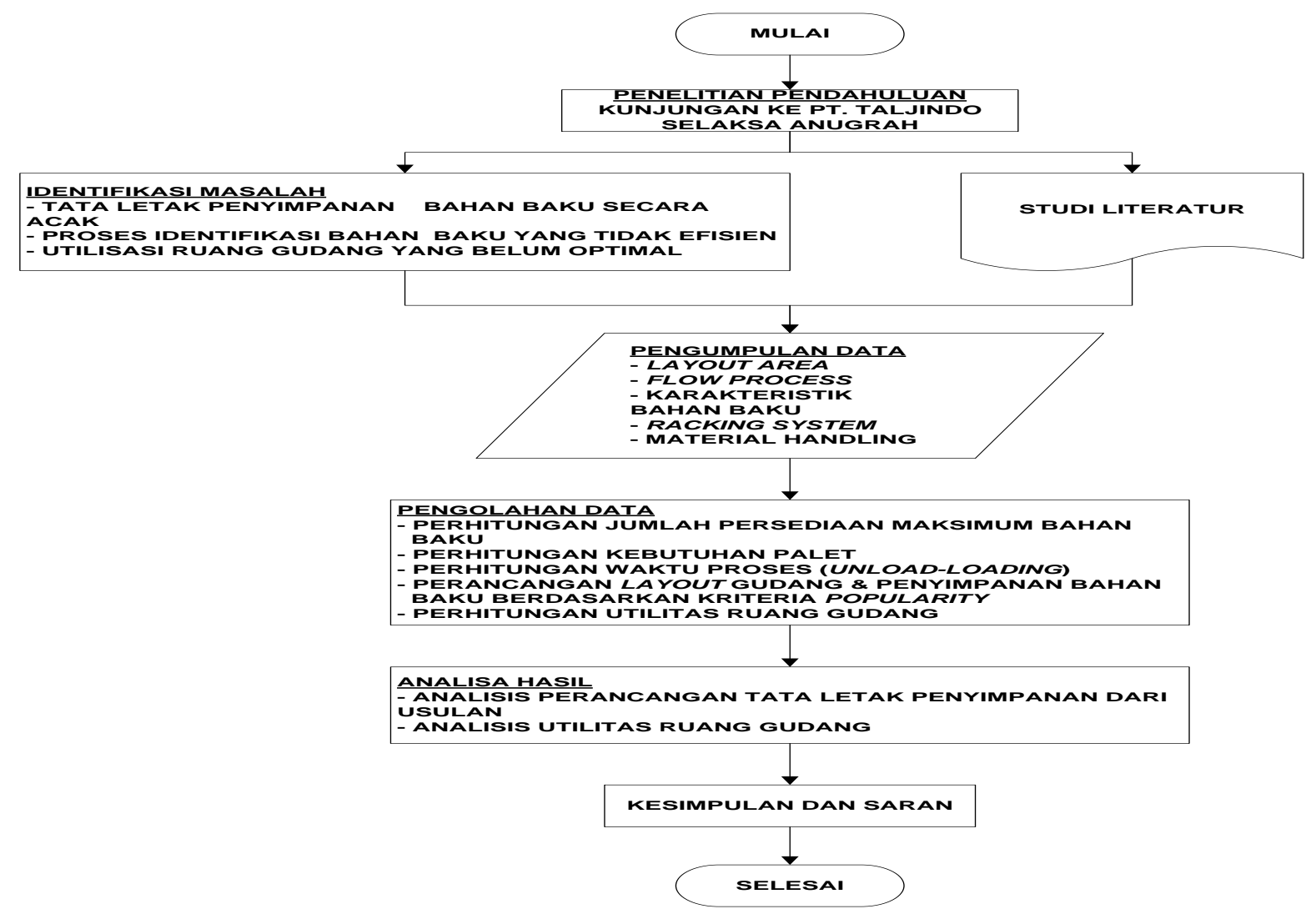

Gambar 1. Metodologi Penelitian 


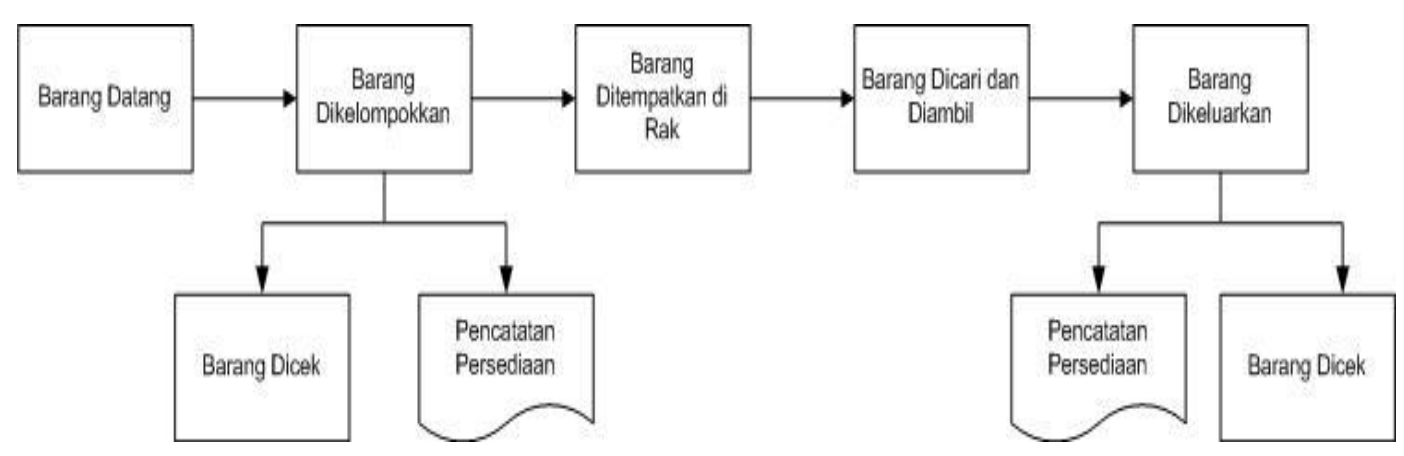

Gambar 2. Flow Process di area Dry J.CO (Unload-Loading)

Tata Letak Penyimpanan Bahan Baku di Area

\section{Dry J.CO Saat Ini}

Volume gudang yang terpakai di area Dry J CO saat ini adalah $\left(55 \mathrm{~m} \mathrm{x} 6,6 \mathrm{~m} \times 6 \mathrm{~m}=2.178 \mathrm{~m}^{3}\right)$, sedangkan layout rak penyimpanan bahan baku dapat dilihat pada Gambar 3.
Pada area Dry J.CO di atas terdapat 3 jenis rak yang digunakan, untuk ukuran dan kapasitas rak dapat dilihat pada Tabel 1 dan Gambar 4.
RAK 1
10 PALET

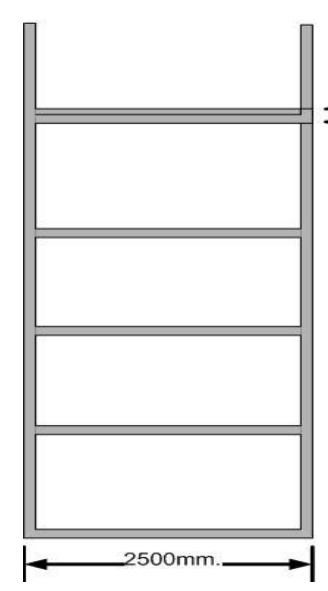

RAK 2
7 PALET

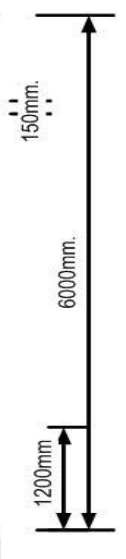

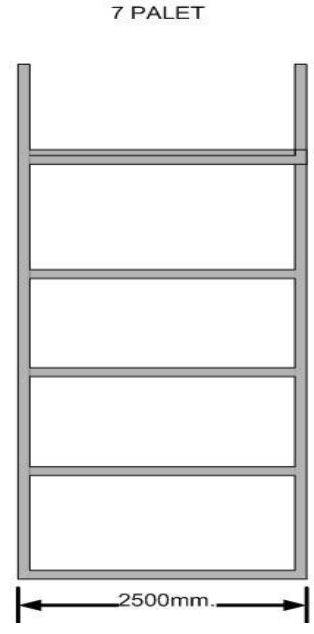
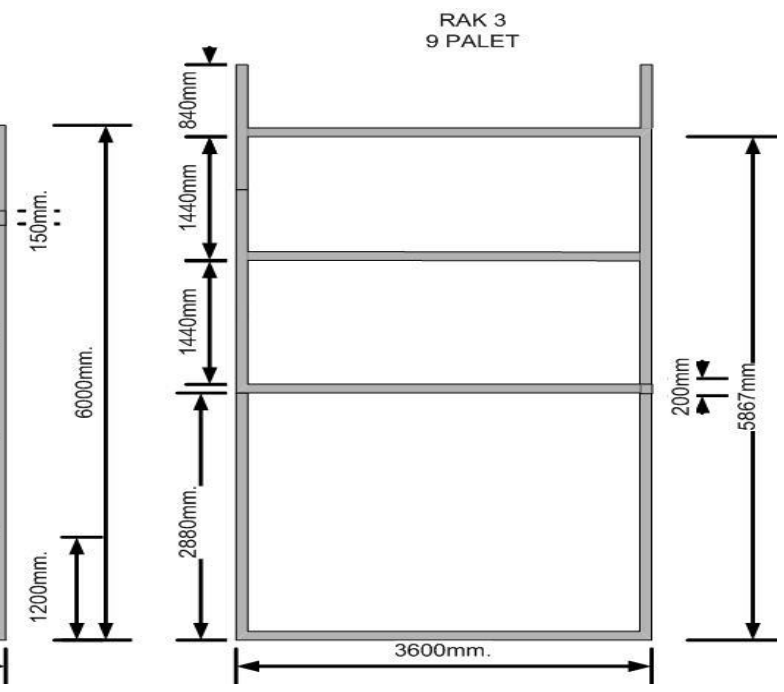

Gambar 3. Layout Rak Penyimpanan Bahan Baku Area Dry J.CO Saat Ini

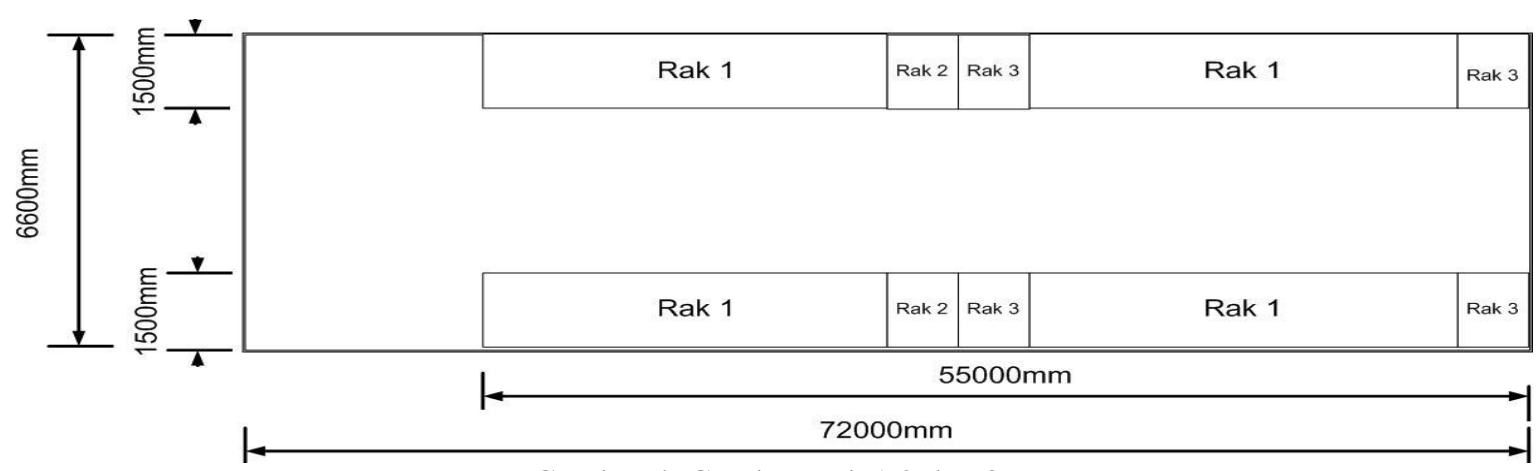

Gambar 4. Gambar Rak 1,2 dan 3 
Tabel 1. Ukuran dan Kapasitas Rak

\begin{tabular}{cccccccc}
\hline No. & $\begin{array}{c}\text { Jenis } \\
\text { Rak }\end{array}$ & $\begin{array}{c}\text { Panjang } \\
(\mathrm{m})\end{array}$ & $\begin{array}{c}\text { Lebar } \\
(\mathrm{m})\end{array}$ & $\begin{array}{c}\text { Tinggi } \\
(\mathrm{m})\end{array}$ & $\begin{array}{c}\text { Jumlah } \\
\text { Rak }\end{array}$ & $\begin{array}{c}\text { Kapasitas } \\
\text { Menampung } \\
\text { Palet /Rak }\end{array}$ & $\begin{array}{c}\text { Jumlah Palet } \\
\text { (Jumlah Rak } \\
\text { x Kapasitas) }\end{array}$ \\
\hline 1 & 1 & 2,5 & 1,5 & 6 & 36 & 10 & 360 \\
2 & 2 & 2,5 & 1,5 & 6 & 2 & 7 & 14 \\
3 & 3 & 3,7 & 1,5 & 6 & 4 & 9 & 36 \\
\multicolumn{7}{c}{ Total Kapasitas Palet yang Tertampung di Rak } \\
\hline
\end{tabular}

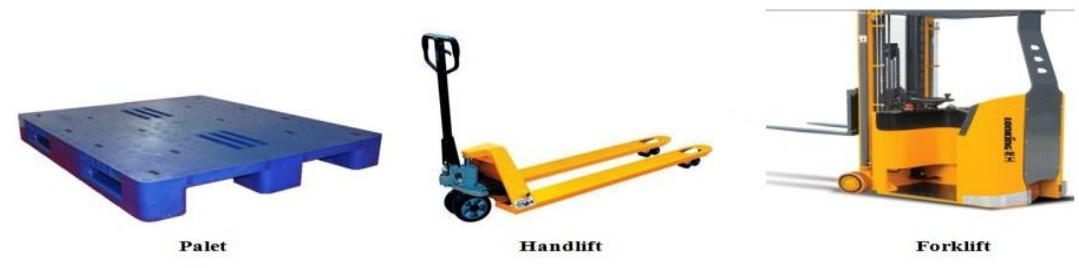

Gambar 5. Palet, Handlift dan Forklift

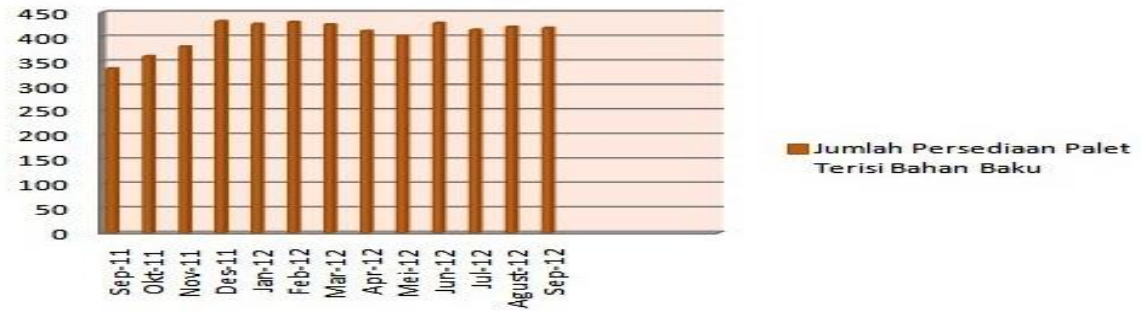

Gambar 6. Histogram Data Persediaan Bahan Baku pada September 2011 - September 2012

\section{Material Handling}

Pada perusahaan ini terdapat material handling berupa palet, handlift sebanyak 6 unit dan forklift sebanyak 2 unit (Gambar 5).

\section{Data Persediaan Bahan Baku}

Data yang dikumpulkan adalah data persediaan bahan baku pada September 2011-September 2012 (Gambar 6).

Berdasarkan data persediaan bahan baku diatas, maka pengolahan data akan dipilih pada bulan Desember 2011, karena pada bulan Desember jumlah persediaan bahan baku di area Dry J.CO pada PT. Talkindo Selaksa Anugrah paling banyak dan kemungkinan terjadinya penumpukan bahan baku sangat tinggi. Data kebutuhan palet didapatkan dari hasil pembagian antara jumlah persediaan tiap bahan baku dibagi dengan kapasitas palet dalam menampung tiap kemasan bahan baku.
Contoh perhitungan kebutuhan palet:

1. Nama Bahan Baku Biscuit Oreo Powder RD

2. Nomer Bahan Baku : 300013

3. Level Persediaan : 535

4. Kapasitas Palet Rata-Rata $: 50 \mathrm{~kg}$ Jumlah palet $=\frac{\text { level stock }}{\text { Kapasitas Palet }}$

$$
\begin{aligned}
& =\frac{535}{50} \\
& =10,7=11 \text { buah }
\end{aligned}
$$

Berdasarkan data perhitungan yang telah dilakukan, dapat disimpulkan bahwa volume bahan baku yang disimpan lebih besar yaitu 432 palet.

Catatan: Penentuan kriteria penyimpanan dengan metode Seiton, yang berarti harus meletakkan barang pada lokasi yang paling tepat/sistematis. Area fast moving, medium moving dan slow moving, pembagian area ini didapatkan dari tingkat pemakaian masing-masing jenis bahan baku dalam setahun. 
Tabel 2. Data Persediaan Bahan Baku pada September 2011, Data Kebutuhan Palet dan Aliran Arus Barang

\begin{tabular}{|c|c|c|c|c|c|}
\hline No & Nama Bahan Baku & Jumlah Persediaan & Kapasitas Palet (KG) & Jumlah Kebutuhan Palet & $\begin{array}{l}\text { Aliran Arus } \\
\text { Bahan }\end{array}$ \\
\hline 1 & Biscuit Oreo Powder RD & 535 & 50 & 11 & Fast \\
\hline 2 & Biscuit Oreo Whole RD & 61 & 50 & 1 & Fast \\
\hline 3 & Margarine & 347 & 40 & 9 & Fast \\
\hline 4 & Cereal Choco Pops & 723 & 50 & 14 & Fast \\
\hline 5 & Cereal Honey Star & 43 & 50 & 1 & Fast \\
\hline 6 & Choc Compound Flakes & 1467 & 1000 & 1 & Fast \\
\hline 7 & Choc Kit Kat & 99 & 40 & 2 & Fast \\
\hline 8 & Choc Paste Hazelnut & 2153 & 1000 & 2 & Slow \\
\hline 9 & Choc Peanut Warna Cha-cha & 67 & 40 & 2 & Fast \\
\hline 10 & Flavouring Choc Syrup & 110 & 50 & 2 & Medium \\
\hline 11 & Choc White Compound Flakes & 768 & 100 & 8 & Fast \\
\hline 12 & Cocoa Butter Subtitute & 128 & 40 & 3 & Fast \\
\hline 13 & Cocoa Powder & 20 & 50 & 1 & Slow \\
\hline 14 & Coffee & 113 & 30 & 4 & Fast \\
\hline 15 & Bubuk Kopi & 155 & 30 & 5 & Fast \\
\hline 16 & Decor Gel Cold & 68 & 30 & 2 & Medium \\
\hline 17 & Diced Peanut & 459 & 100 & 5 & Medium \\
\hline 18 & Dried Cranberries & 22 & 100 & 1 & Medium \\
\hline 19 & Flav Syrup Cream Brulee & 111 & 40 & 3 & Medium \\
\hline 20 & Flav Coffee Mocca Retail & 50 & 40 & 1 & Medium \\
\hline 21 & Flav Syrup Caramel & 178 & 40 & 4 & Medium \\
\hline 22 & Flav Syrup Hazelnut & 61 & 40 & 2 & Medium \\
\hline 23 & Flav Syrup Mint & 84 & 40 & 2 & Medium \\
\hline 24 & Flav Syrup Raspberry & 30 & 40 & 1 & Medium \\
\hline 25 & Flav Syrup Vanilla & 29 & 40 & 1 & Medium \\
\hline 26 & Tepung Terigu & 3585 & 1500 & 2 & Medium \\
\hline 27 & Fruit Can Dark Cherry 425 GR & 775 & 50 & 15 & Slow \\
\hline 28 & Fruit Can Longan 565 GR - NET 230 GR & 2087 & 50 & 42 & Slow \\
\hline 29 & Fruit Can Mand Orange 312 2GR - NET 179 G & 400 & 50 & 8 & Slow \\
\hline 30 & Fruit Can Peach Halve 825 GR - NET 500 GR & 1186 & 50 & 24 & Slow \\
\hline 31 & Ground Black Pepper & 10 & 40 & 1 & Medium \\
\hline 32 & Gula Pasir & 126 & 50 & 2 & Fast \\
\hline 33 & Gula Syrup & 195 & 50 & 4 & Fast \\
\hline 34 & Ice Tea & 363 & 40 & 9 & Fast \\
\hline 35 & Jelly Powder Lyche & 12 & 30 & 1 & Medium \\
\hline 36 & Jelly Powder Orange & 8 & 30 & 1 & Medium \\
\hline 37 & Jelly Powder Plain & 9 & 30 & 1 & Medium \\
\hline 38 & Juhi Powder & 191 & 50 & 4 & Fast \\
\hline 39 & Juice Strawberry & 439 & 50 & 9 & Fast \\
\hline 40 & Milk Coffeemate 380 GR & 498 & 40 & 12 & Fast \\
\hline 41 & Milk Evaporated 380 GR & 546 & 40 & 14 & Fast \\
\hline 42 & Milk UHT Full Cream & 1604 & 40 & 40 & Fast \\
\hline 43 & Minyak Goreng & 92 & 1000 & 1 & Fast \\
\hline 44 & Oregano Flakes & 12 & 30 & 1 & Medium \\
\hline 45 & Paste Banana & 2597 & 1000 & 3 & Slow \\
\hline 46 & Paste Durian & 527 & 1000 & 1 & Slow \\
\hline 47 & Powder Avocado & 928 & 50 & 19 & Slow \\
\hline 48 & Powder Blackforest & 254 & 50 & 5 & Slow \\
\hline 49 & Powder Whip & 194 & 50 & 4 & Slow \\
\hline 50 & Sari Kelapa Kara & 806 & 50 & 16 & Fast \\
\hline 51 & Sauce Barbeque & 40 & 40 & 1 & Slow \\
\hline 52 & Sauce Extra Hot Sachet & 452 & 40 & 11 & Slow \\
\hline 53 & Sauce Ketchup Tomato & 162 & 40 & 4 & Slow \\
\hline 54 & Sugar Palm & 50 & 50 & 1 & Fast \\
\hline 55 & Tea Earl Grey & 323 & 40 & 8 & Fast \\
\hline 56 & Tea English Breakfast & 1950 & 40 & 49 & Fast \\
\hline 57 & Tea Pure Camomile & 645 & 40 & 16 & Fast \\
\hline 58 & Tea Sencha Yamaken & 303 & 40 & 8 & Fast \\
\hline 59 & Tea Thai & 87 & 40 & 2 & Fast \\
\hline 60 & Tepung Gula & 21 & 1000 & 1 & Medium \\
\hline 61 & Tepung Maizena & 27 & 1000 & 1 & Medium \\
\hline 62 & Tuna In Oil In Can 185 GR & 69 & 50 & 1 & Fast \\
\hline 63 & Ragi Coklat & 111 & 50 & 2 & Fast \\
\hline \multirow[t]{2}{*}{64} & Ragi Kering & 45 & 50 & 1 & Fast \\
\hline & Total & & & 432 & \\
\hline
\end{tabular}


Untuk area fast moving dapat diletakan di bagian depan untuk memercepat waktu pengambilan, area medium moving di tengah dan slow moving di belakang. Dengan pengelompokan tersebut diharapkan dapat mempercepat dan mempermudah operator dalam penyimpanan dan pengeluaran barang.

\section{Peta Aliran Proses}

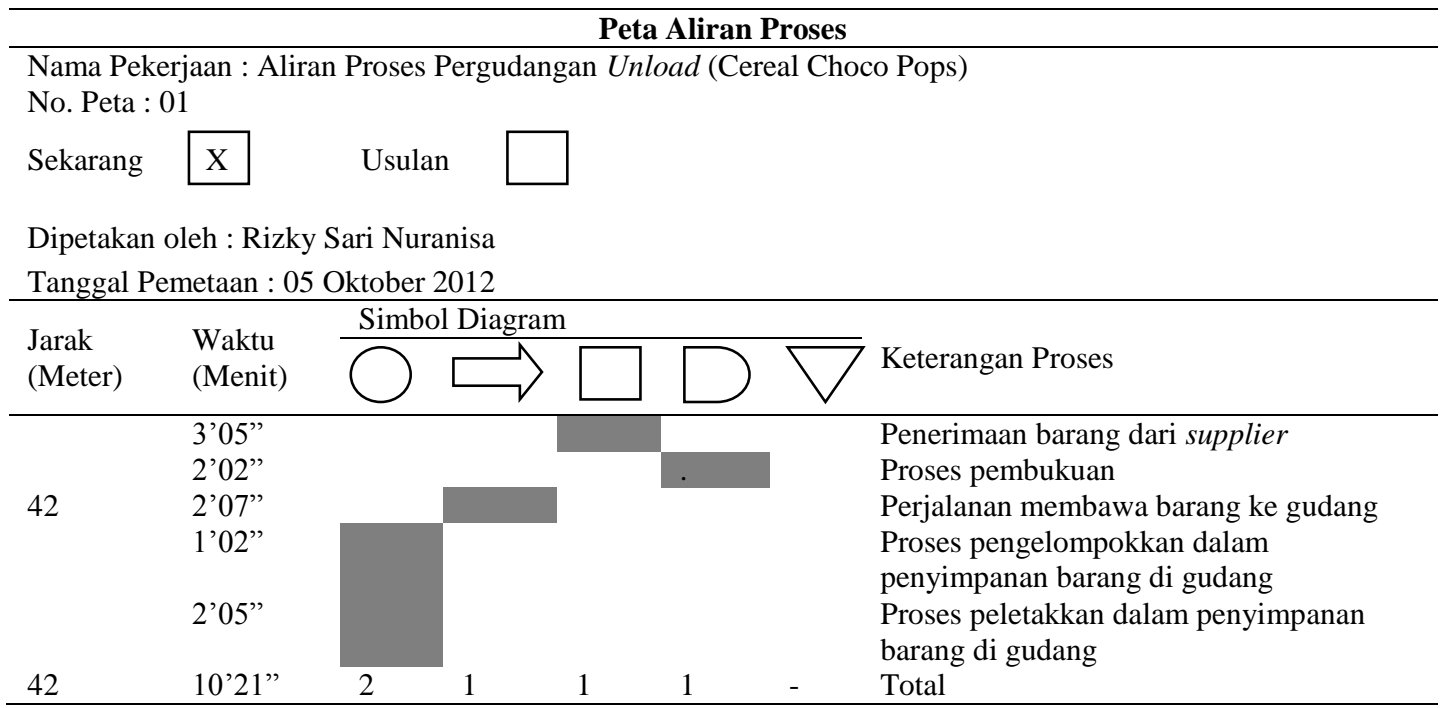

Gambar 7. Peta Aliran Proses Pergudangan (Unload)

Peta Aliran Proses

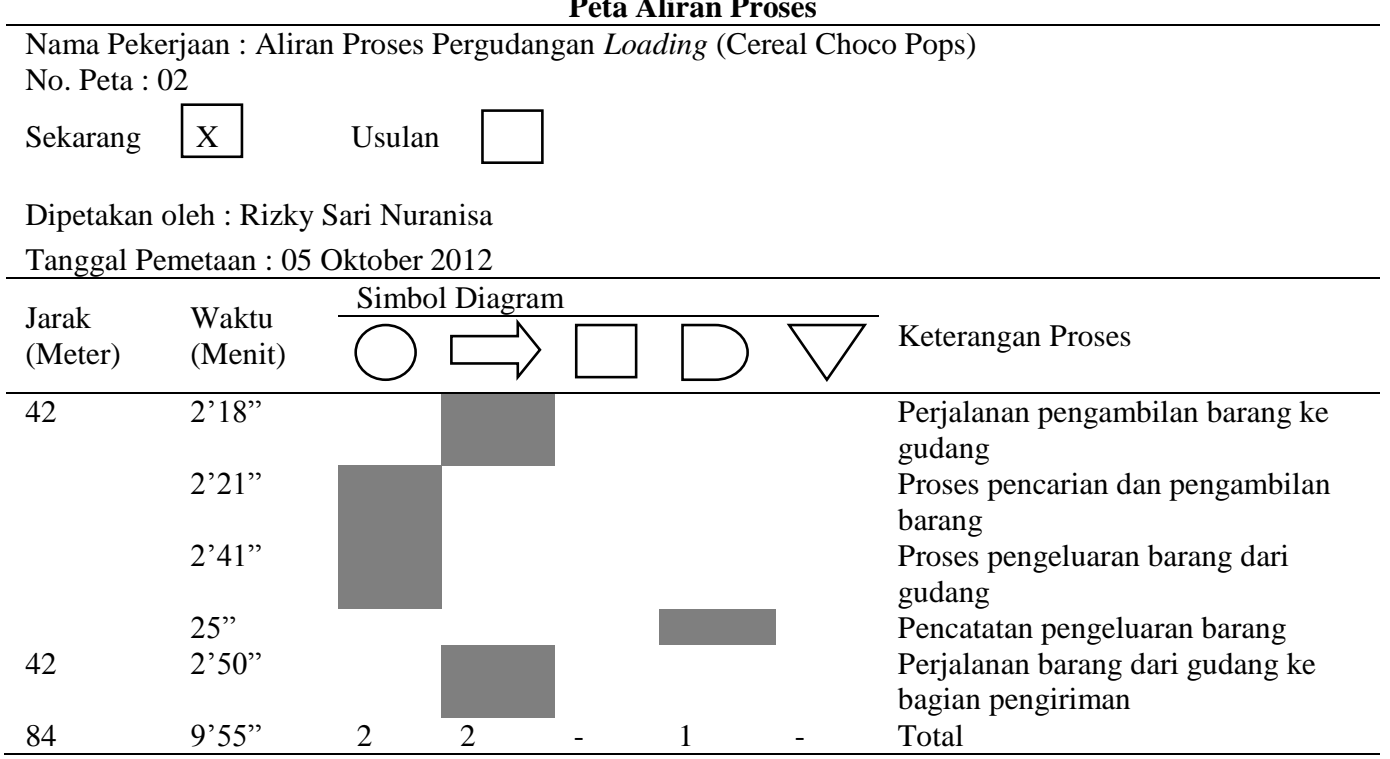

Gambar 8. Peta Aliran Proses Pergudangan (Loading)

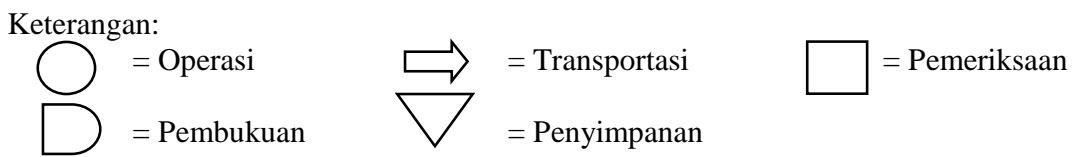


Berdasarkan peta aliran proses di atas, maka disimpulkan bahwa dalam proses pergudangan (Unload-Loading) menghabiskan waktu sebanyak 20 menit 16 detik.

\section{Usulan Perbaikan Perancangan Tata Letak Penyimpanan Bahan Baku}

\section{Usulan Perancangan Penambahan Rak}

Rak yang menjadi usulan untuk dipilih adalah penambahan rak 3 sebanyak 3 buah, yaitu rak penyimpanan sementara yang bisa menampung 9 palet sehingga bisa meningkatkan kapasitas sebanyak 27 palet sehingga Layout detailnya menjadi seperti pada Gambar 9.

\section{Usulan Perancangan Tata Letak Penyimpanan Bahan Baku Berdasarkan Kriteria Popularity Dengan perancangan layout berdasarkan kriteria popularity, maka rangkaian rak di area Dry J.CO}

dibagi menjadi 3 bagian, yaitu daerah merah untuk slow moving, kuning untuk medium moving, dan hijau untuk fast moving bisa dilihat pada Gambar 10.
Analisis Perbaikan Sistem Pencarian dan Pengambilan Bahan Baku
Dari sistem tata letak yang telah diterapkan, operator gudang tidak perlu mengandalkan ingatannya untuk melakukan pencarian lokasi barang, karena sudah adanya dokumentasi dari lokasi penyimpanan bahan baku. Proses pencarian dan pengambilan pun tidak mengalami kesulitan karena sudah ada pembatasan area penyimpanan barang dan klasifikasi aliran arus barang. Hal tersebut dapat mengurangi waktu dari proses pencarian dan pengambilan barang yang dilakukan operator.

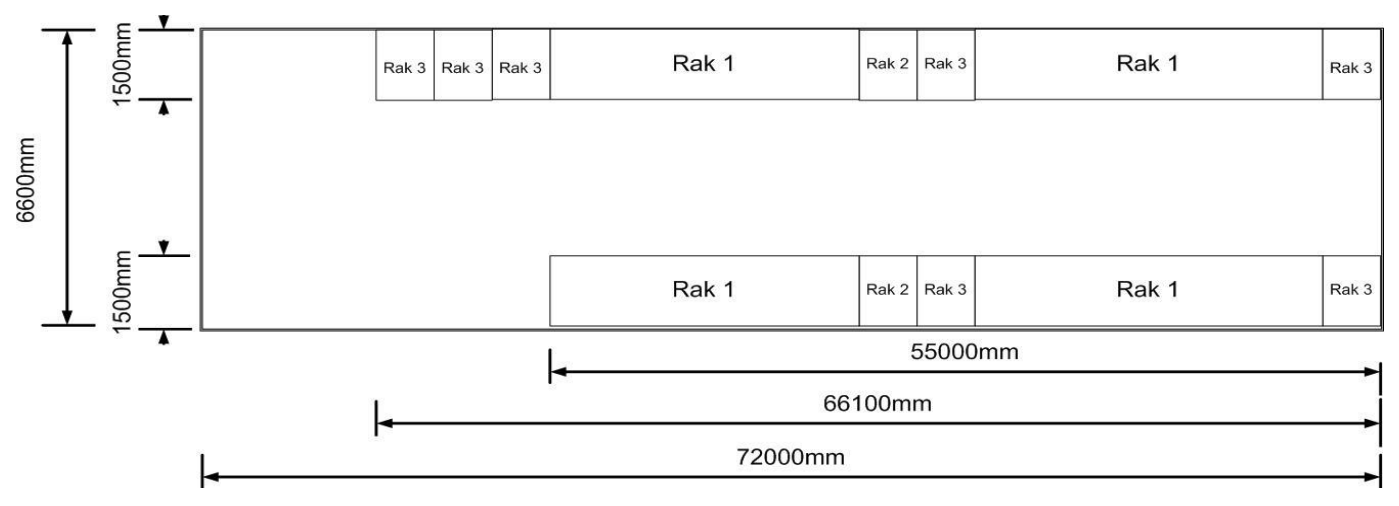

Gambar 9. Layout Rak Penyimpanan Area Dry J.CO Setelah Penambahan

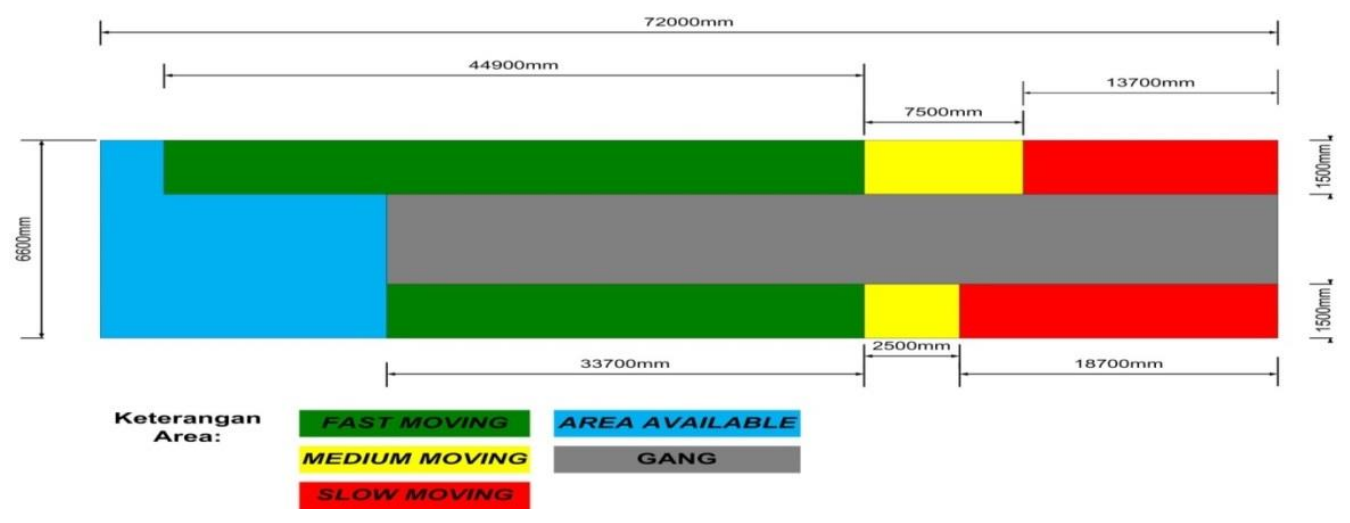

Gambar 10. Layout Rak Penyimpanan Bahan Baku Berdasarkan Popularity (Sesudah penambahan rak) 
Analisis Perbaikan Sistem Penyimpanan Bahan Baku

Penentuan kriteria penyimpanan dengan metode Seiton, yang berarti harus meletakkan barang pada lokasi yang paling tepat/sistematis. Area fast moving, medium moving dan slow moving, pembagian area ini didapatkan dari tingkat pemakaian masing-masing jenis bahan baku dalam setahun. Layout penyimpanan bahan baku berdasarkan klasifikasi aliran arus bahan terlihat pada Gambar 11.

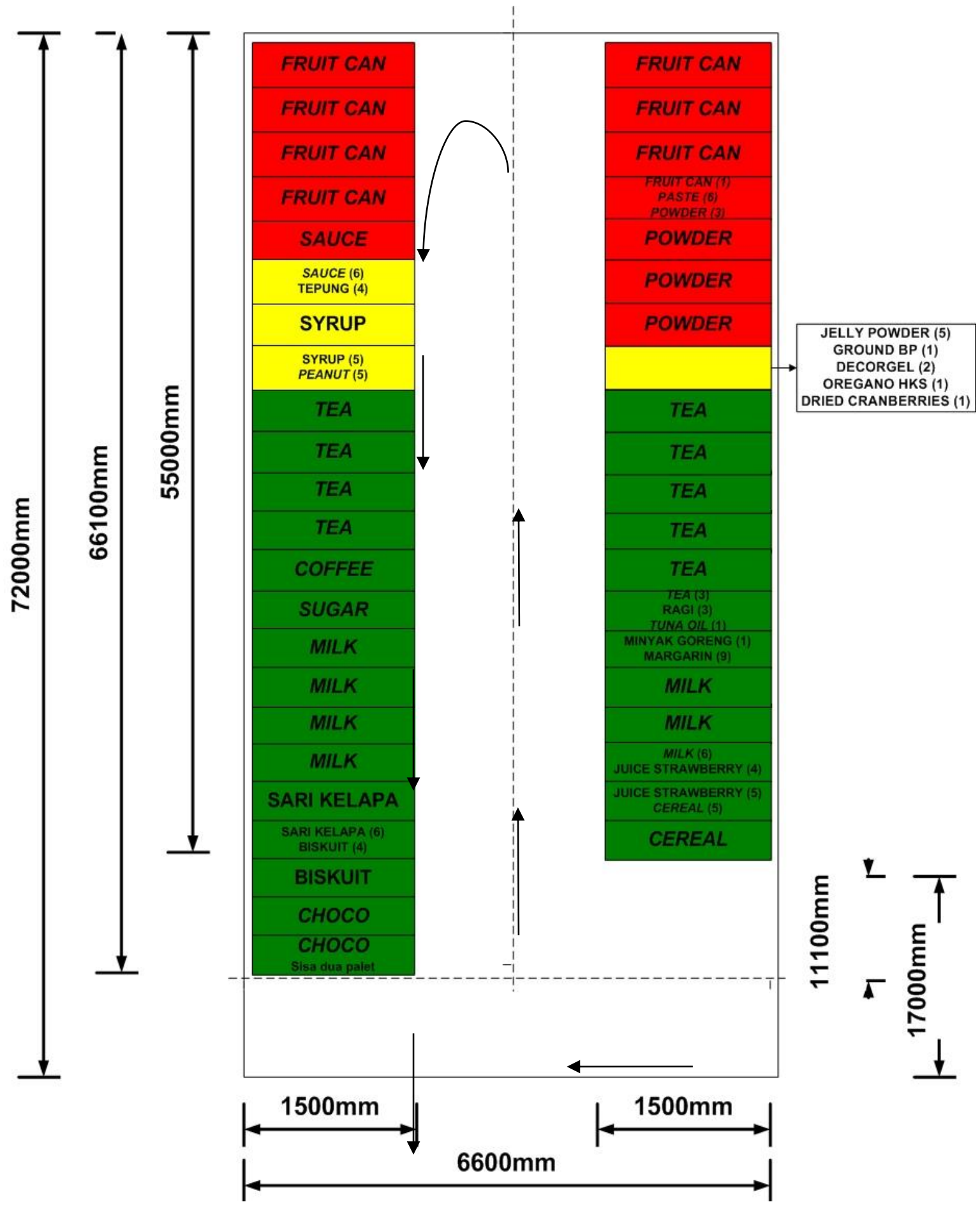

Gambar 11. Layout Area Penyimpanan Bahan Baku Sesuai dengan Aliran Arus Barang 


\section{Analisis Perbaikan Waktu Aliran Proses}

Tabel 3. Peta Aliran Proses Pergudangan (Unload)

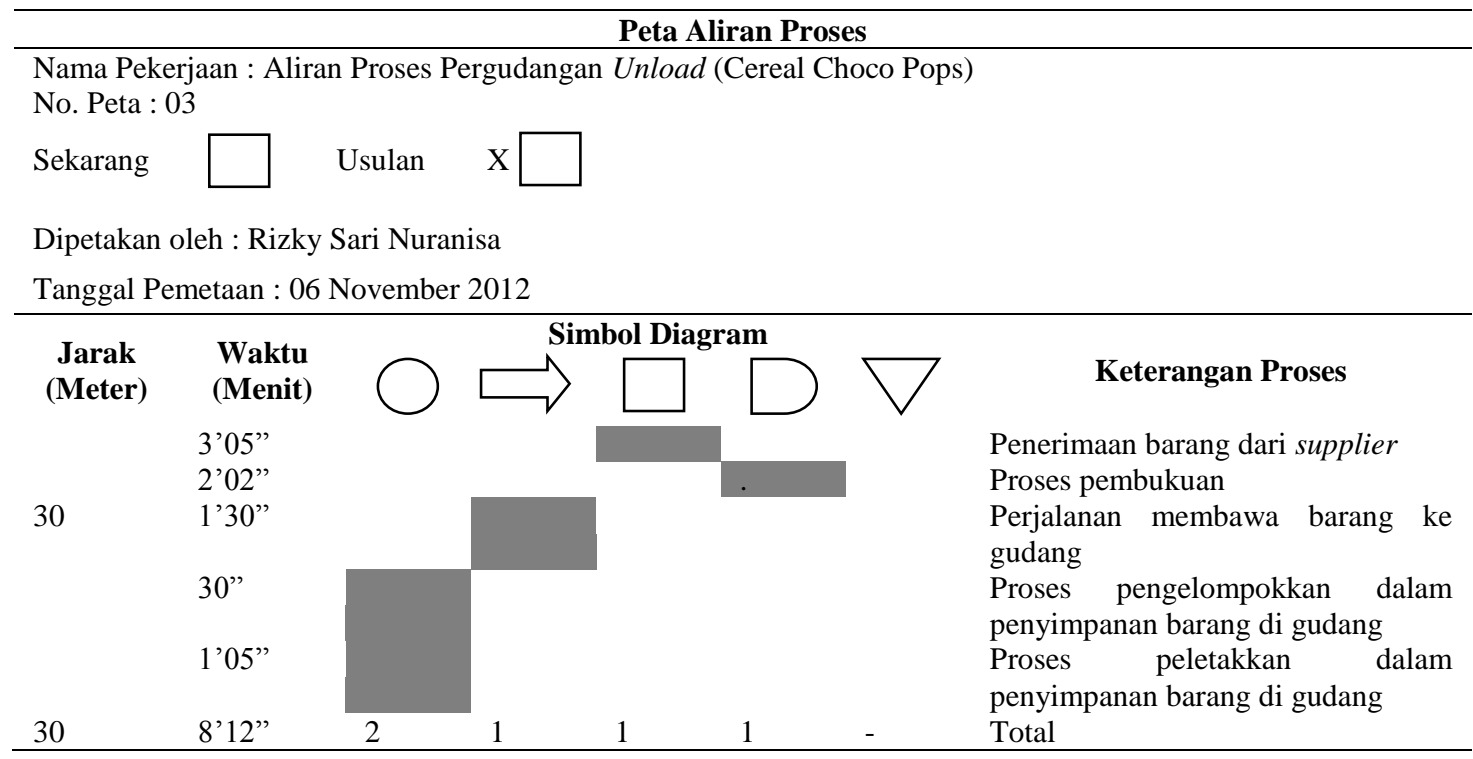

Tabel 4. Peta Aliran Proses Pergudangan (Loading)

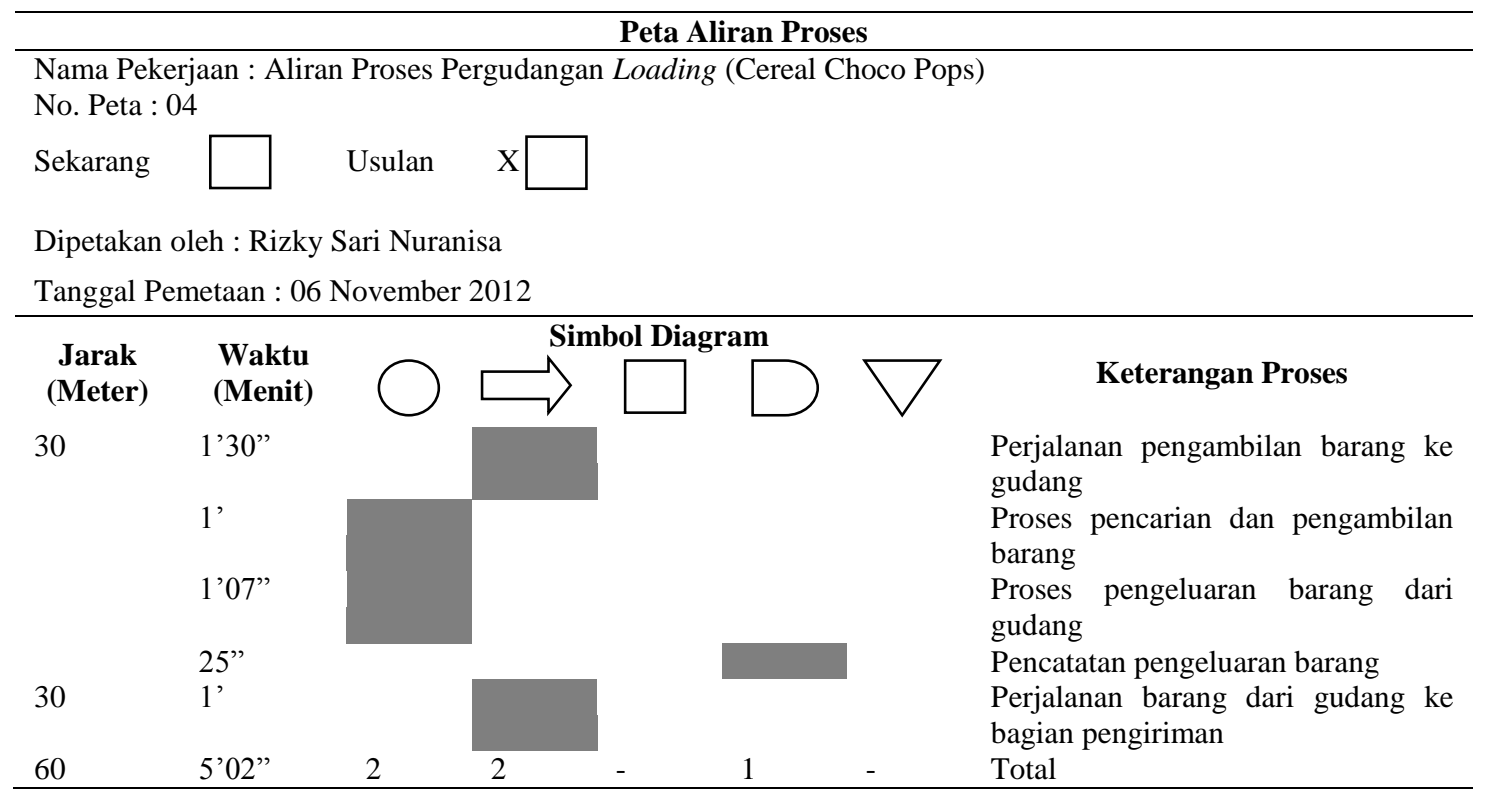

Keterangan:
$=$ Operasi
$=$ Pembukuan
$\square=$ Transportasi
$\square=$ Penyimpanan
$\square=$ Pemeriksaan

Berdasarkan peta aliran proses di atas, total dari waktu proses setelah perbaikan adalah 13 menit 14 detik. Bila dibandingkan dengan waktu proses saat ini yang menghabiskan waktu sebanyak 20 menit 16 detik, maka setelah perbaikan dapat menghemat waktu sebanyak 7 menit 2 detik.

\section{Analisis Perbaikan Utilitas Ruang Gudang}

Berdasarkan analisa utilitas ruang gudang yang ada di PT.Talkindo Selaksa Anugrah maka, berikut ini perhitungan utilitas ruang gudang sebelum dan sesudah dilakukan penambahan rak. 
Utilitas Ruang $=\frac{\text { jumlah area yang digunakan }}{\text { jumlah area yang tersedia }}$

Presentasi Utilitas Ruang saat ini

$=\frac{\left(55 \mathrm{~m} \times 6,6 \mathrm{~m} \times 6 \mathrm{~m}=2.178 \mathrm{~m}^{3}\right)}{\left(72 \mathrm{~m} \times 6,6 \mathrm{~m} \times 7 \mathrm{~m}=3.326,4 \mathrm{~m}^{3}\right)}=0,6547 \times 100 \%=65,47 \%$

Presentasi Utilitas Ruang Usulan

$=\frac{\left(66,1 \mathrm{~m} \times 6,6 \mathrm{~m} \times 6 \mathrm{~m}=2.617,56 \mathrm{~m}^{3}\right)}{\left(72 \mathrm{~m} \times 6,6 \mathrm{~m} \times 7 \mathrm{~m}=3.326,4 \mathrm{~m}^{3}\right)}=0,7869 \times 100 \%=78,69 \%$

Berdasarkan perhitungan utilitas ruang yang telah dilakukan maka dapat ditarik kesimpulan bahwa usulan utilitas ruang gudang lebih baik dibandingkan dengan utilitas ruang gudang awal, karena usulan utilitas ruang gudang mempunyai presentase yang lebih besar dibandingkan utilitas ruang gudang awal.

\section{KESIMPULAN}

Berdasarkan dari hasil pengamatan di lapangan, pengolahan serta analisis data tentang tata letak penyimpanan bahan baku di area Dry J.CO PT.Talkindo Selaksa Anugrah maka dapat ditarik kesimpulan:

1. Kebijakan penyimpanan bahan baku tetap dengan menerapkan metode Seiton dan kriteria popularity. Penerapan kriteria tersebut dapat dilakukan sesuai dengan tujuan yang diinginkan perusahaan yaitu mengoptimalkan proses pergudangan.

2. Pengukuran waktu proses pergudangan mulai dari sistem penerimaan bahan baku dari pemasok, pembukuan, penyimpanan bahan baku, pencarian dan pengambilan serta pengeluaran bahan bak, mendapatkan hasil 20 menit 16 detik. Setelah dilakukan rancangan tata letak usulan, hasil perhitungan waktu proses menjadi 13 menit 14 detik.

3. Dilakukan perhitungan utilitas ruang gudang dengan perbandingan antara jumlah area terpakai dengan jumlah area yang tersedia didapatkan hasil 65,47\%. Setelah dilakukan simulasi perbaikan dengan menambahkan jumlah rak maka didapatkan peningkatan presentase menjadi $78,69 \%$.

4. Utilitas ruang gudang yaitu perbandingan antara jumlah area luas rak yang digunakan untuk meletakkan bahan baku dengan jumlah area yang tersedia saat ini adalah $65,47 \%$. Utilitas ruang gudang dengan layout usulan, yaitu dengan menambahkan jumlah rak maka didapatkan peningkatan utilitas menjadi 78,69\%.

\section{DAFTAR PUSTAKA}

[1] A. M. James, 1990, Tata Letak Pabrik dan Pemindahan Bahan, Penerbit ITB, Bandung.

[2] H. Jay, B Render, 2006, Manajemen Operasi, Edisi7, Penerbit Salemba Empat, Jakarta.

[3] H. Hiroyuki 1995, 5 Pillars of The Visual Workplace, New York: Productivity Press.

[4] S. Wignjoseobroto, 2003, Tata Letak Pabrik Dan Pemindahan Bahan, Penerbit Guna Widya, Surabaya.

[5] SB. Purwanggono, DT Astuti, 2009, Redisain Layout dan Prosedur Untuk Reduksi Waktu Setup Gudang Komponen, Jurnal Ilmiah Teknik Industri Universitas Diponegoro. 4, [30 November 2012].

[6] W. John 2004, Manajemen Pergudangan Seri Manajemen No.57, Penerbit Pustaka Sinar Harapan, Jakarta. 